International Journal of Business Management and Economic Review

Vol. 4, No. 06; 2021

ISSN: 2581-4664

\title{
THE EFFECT OF PARTICIPATION IN BUDGETING, COMPETENCY AND ORGANIZATIONAL COMMITMENT ON BUDGET PERFORMANCE (Study on Govermental Working Unit (SKPK) of Aceh Singkil Regency, Province of Aceh, Indonesia)
}

\author{
Dwi Sumi Rahayu, Ridwan Ibrahim and Mulia Saputra \\ Magister of Accountancy Program,Faculty of Economics and Business, Universitas Syiah Kuala, Banda Aceh, \\ Indonesia
}

http://doi.org/10.35409/IJBMER.2021.3339

\begin{abstract}
This study aims to examine the effect of participation in budgeting, competency and organizational commitment both simultenously and particially on the budget performance of the SKPK of Aceh Singkil Regency. The research population in this study are 46 SKPKs in the district of which consist of the Head of SKPK, Treasurers, and Head of Planning. The research employed primary data that obtained from questionnaires distributed from respondents. While the research data technique was carried out by using documentation technique, the analytical method used is Multiple Linear Regression Analysis. The results indicated that the participation in budgeting, competency and organizational commitment have a significant effect on the budget performance of SKPK in the Regency both simultenously and particially.
\end{abstract}

Keyword: Participation in Budgeting, Competency, Organizational Commitment, Budget Performance.

\section{INTRODUCTION}

Good and accountable local government management can not be separated from the performance and budget of local government. A budget is a short-term plan that is compiled based on a long-term activity plan that has been implemented by the preparation of activities. The public sector budget is related to the process of determining the amount of the allocation of funds for each program and activity in monetary units using public funds. In carrying out its duties, every organization, including the central and regional governments, is required to have a prepared plan and will be used as a guide when carrying out their duties (Prayitno, 2017).

The budgeting process using a performance approach is regulated in Ministry of Domestic Affairs Regulation ( Permendagri) Number 59 of 2007 concerning Amendments to Permendagri Number 13 of 2006 concerning Guidelines for Regional Financial Management . Meanwhile, the guidelines for evaluating the performance of local governments are regulated in Permendagri Number 21 of 2010 concerning Guidelines for the Evaluation of Autonomous Regions of the Results of Expansion after the Enactment of Law Number 22 of 1999 concerning Regional Government.

One of the regions that has implemented autonomy in financial management is Aceh Singkil District. However, until now there are still problems related to budget performance 


\section{International Journal of Business Management and Economic Review}

Vol. 4, No. 06; 2021

ISSN: 2581-4664

in the Regional Government . The problem that occurs is that some items in the financial statements have a lower realization rate than the budget . Another weakness of the budget performance in Aceh Singkil Regency is the inaccuracy of the schedule for the preparation and determination of the Distric Government Budget (APBD) and the budget that is prepared does not accommodate the vision and mission of the regional head, so that many activities that cannot be financed by the APBD ultimately affect the slow absorption of the budget. In addition, various problems also occur in the budget absorption process, such as; The slow tender process, late ratification of Regional Work Unit Budget Implementation Documents (DPA-SKPD), lack of quality Human Resources (SDM), lack of guidance from the central government and other problems related to local government bureaucracy are problems that occur in the budget absorption process (Juliani and Sholihin, 2014).

Low budget absorption is a major problem in the management of government finances. This is because the low level of budget absorption will contribute to the quality of public services and difficulties in achieving economic growth targets (Burhan et al., 2015). Based on the references that researchers have, there are several factors that can affect budget performance such as the low level of participation of budget compilers, weak competence of financial management officials and organizations that do not have a high commitment to achieving organizational goals.

Based on some of the results of previous research, it can be determined the factors that affect budget performance. Firstly, participation in budgeting. In preparing the APBD, local governments have implemented the participation of each work unit in budget preparation. Each SKPD prepares a Budget Work Plan (RKA) which is commonly called the RKA SKPD. In the RKA SKPD, each SKPD has made performance indicators to be achieved for each program and activity to be implemented. The RKA contains the inputs, outputs and outcomes of each program and activity. In this case, budgeting is used in a performance approach, so any planned cost allocation must be linked to the level of service or the results expected to be achieved (Revika, 2015). The results of research by Prayitno (2017) and Revika (2015) show that there is a relationship between budget participation and budget performance of public sector organizations.

Secondly, the competence of the apparatus has an effect on budget performance. One of the main factors that determine whether or not the wheels of government run are human resources (HR). This can be seen from how humans as workers use their physical and psychological potential maximally in achieving organizational goals (institutions). To produce good performance, it must be supported by adequate quality human resources. If the available human resources are competent in their fields, then the performance created will be as needed and according to what they should be (Putri 2014). The results of research by Akram, Agusdin and Irtianna (2017), Putri (2014) and Herriyanto (2012) show that there is an effect of apparatus competence on budget performance.

Thirdly, organizational commitment affects budget performance. In making policies and implementing the budget, conditions are also influenced by external parties. In this case, for example, demands from the Governor / Regent / Mayor, criticism from the public, and mass media coverage. The pressure exerted by these parties can be in the form of regulations, laws and other policies. So that high organizational commitment is needed in 
an effort to improve work unit performance in the implementation of financial management. The level of organizational commitment will greatly determine the performance to be achieved by the organization (Purnomo and Ulyani, 2016). The results of research by Shalikhah (2014), Juliani and Sholihin (2014), Revika (2015), Purnomo and Ulyani (2016) show that there is an effect of organizational commitment on budget performance in public sector organizations.

Based on the problems and description of the results of research that has been described previously, the purpose of this research is u ntuk test the effect of budget participation, competence of personnel and organizational commitment both jointly and separately on budget performance SKPK Aceh Singkil.

\section{LITERATURE REVIEW Budget Performance}

Performance is an overview of the level of achievement of the implementation of an activity / program / policy in achieving the goals, objectives, mission and vision of the organization as stated in the strategic palnning an organization (Mahsun et al., 2011: 141). Budget is a statement regarding the estimated performance to be achieved during a certain period of time expressed in financial terms, while budgeting is a process or method for preparing a budget (Mardiasmo, 2009: 61). Based on the previous description, it can be concluded that budget performance is the level of achievement of an activity that has been determined by the organization in order to achieve organizational goals.

\section{Participation in Budgeting}

Budget participation is the level of involvement and influence of individuals in the budget preparation process. Participation in budgeting is a process in which individuals, whose performance is evaluated and rewarded based on the achievement of budget targets, are involved and have influence in the preparation of budget targets (Brownel, 1982). According to Ebdon and Franklin (2006), participating communities will be very useful in knowing their trade-offs (making decisions on two or more things) so that the government can get valuable input from the community about people's priorities and preferences. According to Siegel and Boulian (1989) participation will allow dysfunctional behavior to occur. Dysfunctional behavior in this case is behavior that is not in accordance with the current regulations. To avoid dysfunctional behavior, government officials are given the opportunity to participate in budgeting.

\section{Competency}

Kharis (2010) explains that individual competence is a person's ability to carry out the tasks and responsibilities given to him with adequate education, training and experience. A person who has competence will work with his knowledge and skills so that he can work easily, quickly, intuitively and with experience can minimize errors. These three tendencies are also in line with the understanding of competence in the explanation of article 3 of PP No.101 of 2000 that what is meant by competence is the ability and characteristics possessed by civil servants in the form of knowledge, skills, and behavioral attitudes needed in carrying out their duties.

\section{Organizational Commitment}




\section{International Journal of Business Management and Economic Review}

Vol. 4, No. 06; 2021

ISSN: 2581-4664

According to Lubis (2010: 54), organizational commitment is the degree to which a worker sides with a particular organization and its goals, and intends to maintain its membership in that organization. Commitment has nothing to do with talent, intelligence, or talent. Someone is said to have organizational commitment if they believe in and accept the goals and values of the organization, are willing to try to achieve organizational goals, have a strong desire to remain a member of the organization for a long time. Organizational commitment is one of the concepts of work attitudes because attitudes toward work are related whether there is a connection and someone's involvement in the organization ( organizational commitment ). The existence of a commitment can be an encouragement for someone to work better or even leave their job due to a demand for other commitments. The right commitment will provide high motivation and have a positive impact on one's performance, especially in budget absorption (Arif and Halim, 2013).

\section{RESEARCH METHOD}

The population of this research is the SKPK Aceh Singkil which includes 46 offices, agencies and agencies in Aceh Singkil Regency. Each SKPK consists of 3 (three) people who will become respondents, namely the Head of the SKPK, the SKPK Treasurer, and the Head of the Planning Division, so that the total respondents are 135 people (45 SKPK x 3 respondents). Sources of data in this study using primary data, namely the acquisition of questionnaires from respondents. While the research data collection technique was carried out by using documentation techniques. The analytical method used is Multiple Linear Regression Analysis.

Operationalization of variables in this study can be described as follows;

a. Budget Performance (Y), it refers to the level of achievement of an activity that has been determined by the organization in order to achieve organizational goals. Budget performance indicators and questionnaires used are based on Lubis (1997) which include: precise, fast, economical and safe. The measurement scale used is an interval scale in the form of a 5-point Likert scale.

b. Participation in budgeting $\left(\mathrm{X}_{1}\right)$, it is a process of individual participation that will be evaluated based on their achievements on the goals to be achieved. Participation indicators in budgeting and questionnaires used based on Ginting (2009) include; initial budget participation, contributions, engagement, opinion requests, opinion polls, and final budget participation. The measurement scale used is an interval scale in the form of a 5point Likert scale.

c. Competency $\left(\mathrm{X}_{2}\right)$, it is related to the ability and characteristics possessed by the apparatus in the form of knowledge, skills, and behavioral attitudes needed in carrying out their duties. Apparatus competency indicators and questionnaires used based on Callista (2016) include; Knowledge, Skill, Motives, Traits, Self-Concept. The measurement scale used is an interval scale in the form of a 5-point Likert scale.

d. Organizational Commitment $\left(\mathrm{X}_{3}\right)$, is the attitude of individuals who are bound to the organization where they work consistently. Indicators of organizational commitment and questionnaires used based on Akram, Agusdin and Irtiana (2017) include; Affective Commitment, Continuance commitment, Normative commitment. The measurement scale used is an interval scale in the form of a 5-point Likert scale.

\section{RESULTS AND DISCUSSION}


International Journal of Business Management and Economic Review

Vol. 4, No. 06; 2021

ISSN: 2581-4664

\section{Results.}

\section{Descriptive Analysis}

Descriptive analysis for each variable in this study was obtained by questionnaires filled out by respondents to the variable; budget performance $(\mathrm{Y})$, budgeting participation $\left(\mathrm{X}_{1}\right)$, competence $\left(\mathrm{X}_{2}\right)$, and organizational commitment $\left(\mathrm{X}_{3}\right)$. The following are descriptive statistical values for each of the research variables in Table 1.

\section{Tabel 1}

\section{Descriptive statistics}

\begin{tabular}{|l|l|l|l|l|}
\hline Information & $\begin{array}{l}\text { Budget } \\
\text { Performance }\end{array}$ & $\begin{array}{l}\text { Participation } \\
\text { in } \\
\text { Budgeting }\end{array}$ & Competence & $\begin{array}{l}\text { Organizational } \\
\text { Commitment }\end{array}$ \\
\hline Average & 4.21 & 4.09 & 4.11 & 4.19 \\
\hline $\begin{array}{l}\text { Standard } \\
\text { Deviation }\end{array}$ & 0.21 & 0.17 & 0.18 & 0.15 \\
\hline Minimum & 3.75 & 3.78 & 3.73 & 3.78 \\
\hline Maximum & 4.88 & 4.33 & 4.33 & 4.44 \\
\hline
\end{tabular}

Based on the results of descriptive statistics, it can be seen that the four research variables, budget performance $(\mathrm{Y})$, budgetary participation $\left(\mathrm{X}_{1}\right)$, competence $\left(\mathrm{X}_{2}\right)$, and organizational commitment $\left(\mathrm{X}_{3}\right)$ show an average value greater than the standard deviation value. This indicates that the four research variables have a more stable rate of data distribution. It can also be seen from the difference in the minimum and maximum values of the four variables which have a range that is not too far.

\section{Research Instrument Testing Results}

a. Based on the results of testing the validity shows that the correlation coefficient obtained from each variable item budget performance $(\mathrm{Y})$, budgetary participation $\left(\mathrm{X}_{1}\right)$, competence $\left(\mathrm{X}_{2}\right)$, and organizational commitment $\left(\mathrm{X}_{3}\right)$ are all above critical value of product moment correlation (correlation coefficient $>0,291$ ) so that the questionnaire used can be declared valid.

b. Based on the p engujian reliability in mind that each instrument in this study reliable (reliably) because the value Cronb ach's Alpha greater than 0,6. So it can be concluded that the questionnaire used as a measurement tool in this study is feasible to use (reliable).

\section{Classical Assumption Testing Results}

Based on the histogram graph, it is known that the observation data is normally distributed where the curve is normal. While the P-Plot graph is known that the points move in the direction of the linear line, so it can be concluded that the research regression model is linear.

Based on the figure tolerance of variable budgetary participation $\left(\mathrm{X}_{1}\right)$, competence $\left(\mathrm{X}_{2}\right)$, and organizational commitment $\left(X_{3}\right)>0,10$, which means that no multikoline a rity between the independent variables. Meanwhile, the VIF value calculation results also showed that none of the independent variables that have a VIF value of more than 10. Thus, it can be concluded that in this study the regression model did not happen multikoline a rity between the independent variables. 
From the graph scatterplot is known that there is no particular pattern in the chart, therefore it can be concluded that the regression model in this study is homoscedastisity or not happen heteroscedastisity.

\section{Regression Testing Results}

Table 2

The results of testing the research regression can be seen in Table 2 below:

\section{Research Regression Testing Results}

\begin{tabular}{|l|l|l|l|l|}
\hline No. & Variable Name & $\begin{array}{l}\text { Regression } \\
\text { Coefficient } \\
(\beta)\end{array}$ & Provisions & Conclusion \\
\hline 1 & $\begin{array}{l}\text { Participation } \\
\text { Budgeting }\left(\mathrm{X}_{1}\right)\end{array}$ & 0.400 & $\beta \neq 0$ & Take effect \\
\hline 2 & Apparatus Competence $\left(\mathrm{X}_{2}\right)$ & 0.412 & $\beta \neq 0$ & Take effect \\
\hline 3 & $\begin{array}{l}\text { Organizational } \\
\text { Commitment }\left(\mathrm{X}_{3}\right)\end{array}$ & 0.505 & $\beta \neq 0$ & Take effect \\
\hline
\end{tabular}

Based on the results of the regression tests, the multiple linear regression equation is obtained as follows:

$\mathrm{KA}=1.883+0,400 \mathrm{PPA}+0,412 \mathrm{KA}+0,505 \mathrm{KO}+\varepsilon$

\section{Discussions}

\section{Effect of Participation in Budgeting on Budget Performance}

The results indicated that budget participation had an effect on budget performance. The regression coefficient $\left(\beta_{1}\right)$ obtained is 0.400 , indicating that each increase in budgeting participation of 1 unit of interval scale will be followed by an increase in budget performance of 0.400 units of interval scale. Obtained a positive effect of budgetary participation on budget performance. This means that if the financial management apparatus participates in budget preparation, the budget performance will get better.

The results of this study are in accordance with the theory expressed by Kung et al. (2013) which states that a predetermined budget functions as a plan and as a performance criterion, that is, the budget is used as a control system to measure managerial or organizational performance. The same thing was expressed by Yahya et al. (2008) which explains that budget performance is considered effective if budget objectives can be achieved and subordinates have the opportunity to be involved or participate in the budget preparation process. The results of this study are also in line with the results stated by Prayitno (2017) which prove that budget participation has a positive effect on the performance of the East Lampung Regency Government budget preparation. This means that the better the participation in budgeting, the better the managerial performance in budgeting in East Lampung Regency.

\section{Effect of Competence Apparatus on Budget Performance}

The results showed that the competence of the apparatus had an effect on budget performance. The regression coefficient $\left(\beta_{2}\right)$ obtained is 0.412 , indicating that each increase in the competence of the apparatus by 1 interval scale unit will be followed by an increase in budget 


\section{International Journal of Business Management and Economic Review}

Vol. 4, No. 06; 2021

ISSN: 2581-4664

performance of 0.412 interval scale units. Obtained a positive effect of apparatus competence on budget performance. This means that if the financial management apparatus has good competence related to budgeting, the budget performance will get better.

The results of this study are in accordance with the theory expressed by Drina, Sulandari, and Rihandoyo (2014) which states that the apparatus as labor in the implementation of budgeting is seen in the human function as a work unit that has tasks, one of which is a financial manager who must understand well the procedures. and financial management procedures. This is also in accordance with Putri (2014) which states that apparatus has a relationship with planning, because there are objectives of apparatus planning which include individual interests, organizational interests and national interests. The results of this study are in accordance with the results of research conducted by Putri (2014) which proved that apparatus competence has a significant effect on budget absorption in the SKPD of the Bengkulu Provincial Government. The results of this study are also supported by the results of Wang's (1999) study which revealed his findings that Florida officials as research respondents generally agreed that the clarity of organizational goals and adequate performance measurement must be carried out by competent officials in implementing effective budget performance.

\section{Effect of Commitment of organizations on Budget Performance}

The results show that organizational commitment has an effect on budget performance. The regression coefficient $\left(\beta_{3}\right)$ obtained is 0.505 indicating that each increase in organizational commitment by 1 interval scale unit will be followed by an increase in budget performance of 0.505 interval scale units. Obtained a positive effect of organizational commitment on budget performance. This means that if the financial management apparatus, both upper and lower levels, have a strong organizational commitment, the better the budget performance.

The results of this study are in accordance with the theory expressed by Purnomo and Ulyani (2016) which states that making policies and implementing budgets is also influenced by the conditions of external parties. This is also in accordance with the statement of Putri, Yuniarta and Prayudi (2017) which proves that officials who are committed to achieving goals will strive to achieve them and fully support the values and goals the organization wants to achieve. The results of this study are in accordance with the results of research conducted by Purnomo and Ulyani (2016) which provide results that organizational commitment has a significant effect on budget performance in the Lebak Regency Government .

\section{CONCLUSIONS AND SUGGESTIONS}

\section{Conclusions}

It revealed that the participation in budgeting, competency and organizational commitment have a significant influence on the budget performance of SKPK in the Regency both simultenously and particially

\section{Recomendations}




\section{International Journal of Business Management and Economic Review}

Vol. 4, No. 06; 2021

ISSN: 2581-4664

1. For the improvement Regency's performance in terms of budgetary participation, it is enccourage that the apparatus fully participates and contributes in budget preparation, so that the determined budget allocations can be identified by clear, transparent and accountable manner.

2. In terms of apparatus competency, it is recommended SKPK's officials to enhance their competencies related to regional financial management or budgeting in particular so that officials have the capacity to minimize the occurrence of fraud incidents in budgeting which can ultimately improve SKPK performance.

3. Regarding the organizational commitment, it is recommended to provide opportunities for selfdevelopment for apparatus, increase responsibility for their works and organization and impose sanctions for officials who are found guilty. By doing this, it is expected to increase the commitment of these officials for their organizations.

\section{REFERENCES}

Akram, Agusdin, \& E. Irtianna. (2017). Effect of Budgeting, Competence of Human turnResources, Organizational Commitment, Drug Procurement Process and Regulations on Budget Funds Absorption Capitation National Health Insurance Program on Health Center in Central Lombok. International Conference and Call for Papers. 167-192.

Arif, E. \& A.Halim. (2013). Identifikasi Faktor-Faktor Penyebab Minimnya Penyerapan Anggaran APBD Kabupaten/Kota di Propinsi Riau tahun 2011. Tesis. Riau: Universitas Islam Riau.

Burhan, J., Sirojuzilam, Erlina, \& N.Y. Kahar. (2015). Regional Planning and Development of Kota Medan: Effect On Electrical Power Distribution. International Journal of Applied Engineering Research. 10 (17).

Brownell, P. (1982). The Role of Accounting Data in Performance Evaluation, Budgetary Participation and Organizational Effectiveness. Journal of AccountingResearch, 20 (1), $766-777$.

Drina, R. M., S. Sulandari, \& Rihandoyo. (2014). Pengaruh Kompetensi Sumber Daya Manusia dan Budaya Organisasi terhadap Kinerja Badan Perencanaan Pembangunan Daerah Kabupaten Batang. Jurnal Universitas Diponegoro, 1-11.

Ebdon, C., \& A. L. Franklin. (2006). Citizen Participation in Budgeting Theory. Public Administration Review, 66 (3): 437-447.

Herriyanto, H. (2012). Faktor-faktor yang Mempengaruhi Keterlambatan Penyerapan Anggaran Belanja Pada Satker Kementrian/Lembaga di Wilayah Jakarta. Tesis, Program Studi Perencanaan dan Kebijakan Publik, Universitas Indonesia, Jakarta.

Juliani, D., \& M. Sholihin. (2014). Pengaruh Faktor-Faktor Kontekstual Terhadap Persepsian Penyerapan Anggaran Terkait Pengadaan Barang/Jasa. Jurnal Akuntansi dan Keuangan Indonesia, 11(2), 177-199.

Kharis, A. (2010). Pengaruh Kualitas Sumber Daya manusia Terhadap Pelaksanaan Sistem Pengendalian Intern pada PT. Avia Avian. Artikel Online diakses melalui https://core.ac.uk pada 10/09/2019.

Kung, F., Huang, C., Cheng, C. (2013). An Examination Of The Relationshipsamong Budget Emphasis, Budget Planning Models And Performance, Management Decision, 51 (1), 120140.

Mardiasmo. (2009). Akuntansi Sektor Publik. IV ed. Yogyakarta: Andi Offset. 


\section{International Journal of Business Management and Economic Review}

Vol. 4, No. 06; 2021

ISSN: 2581-4664

Prayitno, D. (2017). Pengaruh Budget Planning Model Terhadap Kinerja Penyusunan Anggaran Pemerintah Daerah Kabupaten Lampung Timur. Tesis. Pascasarjana Ilmu Akuntansi Fakultas Ekonomi Dan Bisnis Universitas Lampung.

Purnomo, A. D., \& Ulyani. (2016). Analisis Faktor - Faktor Yang Mempengaruhi Kinerja Anggaran Pada Pemerintahan Kabupaten Lebak. Jurnal Studia Akuntansi dan Bisnis. 4 (1), $1-6$.

Putri, C.T. (2014). Analisis Faktor-Faktor yang Mempengaruhi Penyerapan Anggaran pada Satuan Kerja Perangkat Daerah di Pemerintah Provinsi Bengkulu.Artikel online diakses melalui repository.unib.ac.id pada 10/09/2019.

Putri, K.M.R., G.A. Yuniarta, \& M.A. Prayudi. (2017). Pengaruh Perencanaan Anggaran, Kualitas Sumber Daya Manusia dan Komitmen Organisasi terhadap Penyerapan Anggaran. eJournal S1 Ak Universitas Pendidikan Ganesha. 8(2), 1-12.

Peraturan Menteri Dalam Negeri Nomor 21 Tahun 2011. Tentang Perubahan Kedua Atas Peraturan Menteri Dalam Negeri Nomor 13 Tahun 2006. Tentang Pedoman Pengelolaan Keuangan Daerah.

Permendagri No. 13 Tahun 2006 tentang Pengelolaan Keuangan Daerah. Jakarta.

Revika, R. (2015). Pengaruh Kualitas Sumber Daya Manusia, Komitmen Organisasi, Komunikasi Organisasi, dan Partisipasi Anggaran terhadap Kinerja Satuan Kerja Perangkat Daerah (SKPD) di Kota Payakumbuh. JOM FEKON, 2 (1), 1-15.

Siegel, G. \& H. R. M. Boulian. (1989). Behavioral Accounting. Cincinati, Ohio: South-Western Publishing Co.

Undang-Undang Republik Indonesia Nomor 22 Tahun 1999 tentang Pemerintah Daerah.

Wang, X. H. (1999). Conditions To Implement Outcome-Oriented Performance Budgeting: Some Empirical Evidence. Journal of Public Budgeting, Accounting \& Financial Management. 11 (4), 533. 